\title{
Recent Progress on Endohedral Metallic Fullerenes
}

\author{
Wei Yang, Xiaomeng Li, and Ning Chen* \\ Laboratory of Advanced Optoelectronic Materials, College of Chemistry, Chemical Engineering and \\ Materials Science, Soochow University, Suzhou, Jiangsu 215123, China \\ Email: chenning@suda.edu.cn (N. C.)
}

\begin{abstract}
Endohedral metallic fullerenes (EMFs), featured by the encapsulation of metal ions, molecules and clusters inside the hollow sphere of carbon cage, have drawn great attention in the fullerene research field because of their unique structures and properties. In this minireview, we reviewed the most recent development in this area, focusing mainly on the large EMFs and magnetic EMFs. The relevance between the large carbon cage and cluster was discussed and the paramagnetism and single-molecule magnetism of EMFs, which are controlled by spin single electron and the coupling of f-shell of metal ions, were summarized.
\end{abstract}

Keywords endohedral metallic fullerenes, large endohedral fullerenes, paramagnetism, single-molecule magnetism

\section{Introduction}

Fullerenes, a kind of zero-dimensional carbon material, are empty carbon cages consisting of fused hexagons and pentagons. ${ }^{[1]}$ Metal ions ${ }^{[2-4]}$ and clusters ${ }^{[5-8]}$ can be encapsulated into the hollow cavity of fullerene cages, forming endohedral metalfullerenes (EMFs). The otherwise unstable metal ions or clusters and the carbon cage can be stabilized by the electron transfer between them. ${ }^{[9,10]}$ EMFs can be categorized as classical EMFs and clusterfullerenes (CFs). ${ }^{[1]}$ Classical fullerenes include mainly monometallofullerenes, ${ }^{[12,13]}$ dimetallofullerenes $^{[14-16]}$ and trimetallofullerenes. ${ }^{[17]} \mathrm{CFs}$, depending on the structures of encapsulated clusters, can be classified as nitride $\mathrm{CFs},{ }^{[18-21]}$ carbide $\mathrm{CFs},{ }^{[22-25]}$ hydrocarbide $\mathrm{CFs}^{[26,27]}$ carbon nitride CFs, ${ }^{[27,28]}$ sulfide CFs, ${ }^{[29,30]}$ and oxide CFs. ${ }^{[31,32]}$

In general, fullerenes with cages comprising over 88 carbon atoms are categorized as large fullerenes. Recently, researchers found that large fullerenes could be the transition state between small fullerenes and carbon nanotubes (CNTs) ${ }^{[33]}$ Empty fullerenes, e.g., $D_{5 \mathrm{~h}}(1)-\mathrm{C}_{90}, D_{3 \mathrm{~d}}(3)-\mathrm{C}_{96}, D_{5 \mathrm{~d}}(1)-$ $\mathrm{C}_{100}$, and $D_{2}(812)-\mathrm{C}_{104}$, have been crystallographically identified and their structures were found to be similar to end- capped CNTs. ${ }^{[34]}$ Intriguingly, Echegoyen and co-workers ${ }^{[35]}$ isolated and crystallographically characterized non-classical, heptagoncontaining $\mathrm{Sc}_{2} \mathrm{C}_{2} @ \mathrm{C}_{\mathrm{s}}$ (hept)- $\mathrm{C}_{88}$, finding that the formation of such a structure could be ascribed to a direct $C_{2}$ insertion into the outer cage of the recently reported smaller EMF, $\mathrm{Sc}_{2} \mathrm{C}_{2} @$ $\mathrm{C}_{2 \mathrm{v}}(9)-\mathrm{C}_{86}$.

On the other hand, magnetic EMFs have also aroused heated attention recently. ${ }^{[36-39]}$ Magnetic fullerenes are mainly classified as paramagnetic EMFs and single-molecule magnetic (SMM) EMFs. Paramagnetic EMFs, such as $\mathrm{Sc}_{3} \mathrm{C}_{2} @$ $\mathrm{C}_{80},{ }^{[40]} \mathrm{Y}_{2} @ \mathrm{C}_{79} \mathrm{~N}^{[41]}$ and $\mathrm{Sc}_{4} \mathrm{O}_{2} @ \mathrm{C}_{80},{ }^{[42]}$ can provide abundant structural information such as metal-metal bonding, ${ }^{[42]}$ spincharge separation, ${ }^{[43]}$ spin flow. ${ }^{[44]}$ Due to the stability and sensitivity of ESR signals, they can be applied in molecule magnets and quantum information processing. ${ }^{[11]}$ Recently, clusterfullerenes, such as DySc ${ }_{2} \mathrm{~N} @ \mathrm{C}_{80},{ }^{[45]} \mathrm{Dy}_{2} \mathrm{ScN} @ \mathrm{C}_{80},{ }^{[46]} \mathrm{Dy}_{2} \mathrm{~S} @ \mathrm{C}_{82}{ }^{[47]}$ and TbNC@ $\mathrm{C}_{82}{ }^{[48]}$ were found to have excellent SMM proper- ties. These EMFs based on single-molecule magnets were expected to have potential applications in high density information storage, quantum calculation, spintronics and some other sophisticated equipment. ${ }^{[49,50]}$

In this minireview, we summarized the recent development in the endohedral fullerene field, focusing mainly on large endohedral clusterfullerenes reported to date, especially their molecular structures, properties, and the effect of the size of carbon cage on the encapsulated species. We also reviewed recently discovered magnetic metallofullerenes and chemicallymodified magnetic EMFs.

\section{Large endohedral metallic fullerenes}

The low yield, complex structures, difficulty of extraction and isolation have hindered the detailed research on large EMFs for a long time. ${ }^{[51,52]}$ Only recently, major advances were achieved in this field and the reported large EMFs family had been expanded greatly, ${ }^{[3,54]}$ including: (i) monometallo- fullerenes, i.e., $\mathrm{M} @ \mathrm{C}_{94}(\mathrm{M}=\mathrm{Tm}, \mathrm{Ca})^{[55]}$ and $\mathrm{Sm} @ \mathrm{C}_{2 n}(2 n=90,92$, 94), ${ }^{[56-58]}$ (ii) dimetallofullerenes, i.e., $\mathrm{La}_{2} @ \mathrm{C}_{100}{ }^{[15]} \mathrm{Sm}_{2} @ \mathrm{C}_{104}{ }^{[59]}$ and $\mathrm{Dy}_{2} @ \mathrm{C}_{2 n}(2 n=94-100){ }^{[14]}$ (iii) clusterfullerenes, i.e., $\mathrm{Sc}_{2} \mathrm{C}_{2} @ \mathrm{C}_{88},{ }^{[35]} \mathrm{La}_{2} \mathrm{C}_{2} @ \mathrm{C}_{2 n}(2 n=90,92,94,96,98,102$, $104),{ }^{[7,60]} \mathrm{Gd}_{2} \mathrm{C}_{2} @ \mathrm{C}_{92},{ }^{[61]} \mathrm{La}_{3} \mathrm{~N} @ \mathrm{C}_{2 n}(2 n=88,92,96),{ }^{[62]} \mathrm{Dy}_{3} \mathrm{~N}$ $@ \mathrm{C}_{2 n}(2 n=88-108),{ }^{[63]} \mathrm{Ce}_{3} \mathrm{~N} @ \mathrm{C}_{2 n}(2 n=88-106)^{[64]}$ and $\operatorname{Pr}_{3} \mathrm{~N}$ $@ \mathrm{C}_{2 n}(2 n=88-100),{ }^{[64]}$

In 2012, Dorn and co-workers ${ }^{[65]}$ carried out a series of research on $\mathrm{Y}_{2} \mathrm{C}_{2} @ \mathrm{C}_{2 n}(2 n=82,84,92)$. The $\mathrm{Y}_{2} \mathrm{C}_{2}$ clusters were found to transform a butterfly shape to a linear structure as cage size increased. They predicted that linear $\mathrm{Y}_{2} \mathrm{C}_{2}$ cluster structures are feasible if the fullerene cage is a relatively large cage of at least 100 carbons or has an unusual shape (Figure 1). In 2015, Lu and co-workers ${ }^{[33]}$ isolated successfully and crystallographically characterized $\mathrm{La}_{2} \mathrm{C}_{2} @ D_{5}(450)-\mathrm{C}_{100}$. It was found that by encapsulating $\mathrm{La}_{2} \mathrm{C}_{2}$ cluster, instead of $\mathrm{La}_{2}$, $\mathrm{C}_{2}$-unit acts as a molecular spring that attracts the surrounding cage carbon atoms through strong interactions with the two moving lanthanum ions and a $5 \%$ axial compression of $\mathrm{La}_{2} \mathrm{C}_{2} @ D_{5}(450)-\mathrm{C}_{100}$ was induced. In 2016, they carried fol- 
lowing research on $\mathrm{La}_{2} \mathrm{C}_{2} @ C_{\mathrm{s}}(574)-\mathrm{C}_{102}$ and $\mathrm{La}_{2} \mathrm{C}_{2} @$ $C_{2}(816)-C_{104},{ }^{[7]}$ and found that, instead of the common butterflylike structure frequently detected in smaller fullerenes, the interior $\mathrm{La}_{2} \mathrm{C}_{2}$ clusters of $\mathrm{La}_{2} \mathrm{C}_{2} @ \mathrm{C}_{\mathrm{s}}(574)-\mathrm{C}_{102}$ and $\mathrm{La}_{2} \mathrm{C}_{2} @$ $C_{2}(816)-C_{104}$ exhibited unexpected planar configuration to achieve strong metal-cage interactions. In 2017, a series of large carbide cluster metallofullerenes $\mathrm{La}_{2} \mathrm{C}_{2} @ \mathrm{C}_{2 n}(2 n=90-98)$ were further studied by $\mathrm{Lu}$ and co-workers. ${ }^{[60]}$ Through this study, they came to the conclusion that $\mathrm{La}_{2} @ \mathrm{C}_{2 n}(2 n=92-106)$ series tend to form the corresponding carbide metallofullerenes $\mathrm{La}_{2} \mathrm{C}_{2} @ \mathrm{C}_{2 n}(2 n=90-104)$ rather than the dimetallofullerenes, which ensures strong metal-cage interactions by partially neutralizing the charges from the metal ions and by fulfilling the coordination requirement of the $\mathrm{La}^{3+}$ ions as much as possible. On the other hand, the same group revealed that Lu-containing EMFs with smaller cages, $\mathrm{Lu}_{2} @ \mathrm{C}_{2 n}(2 n=82,84,86),{ }^{[2]}$ prefer to form dimetallofullerenes instead of the common carbide structures. Theoretical calculations reveal unambiguously that dimetallofullerenes are thermodynamically favorable for Lu-containing EMFs because of the formation of a metal-metal bond. All of these results suggest that geometric matching between the carbon cages and the encapsulated cluster is an important factor for the stabilization of the large endohedral fullerenes.

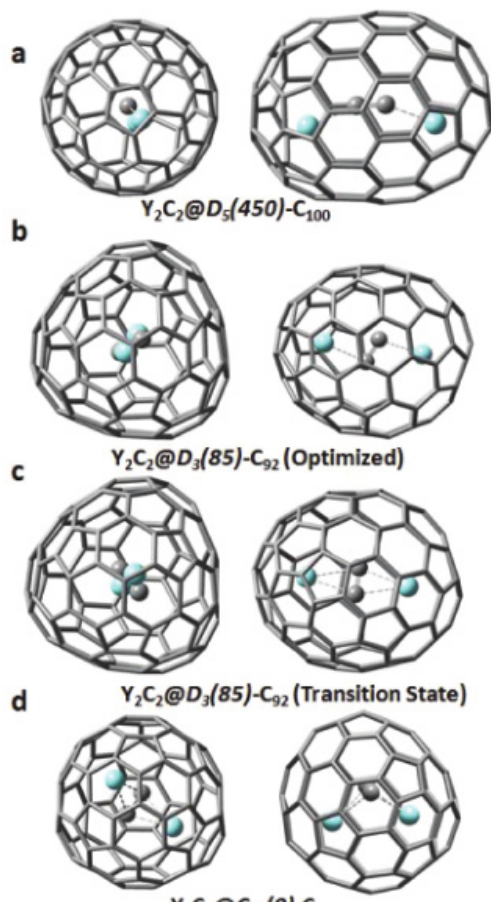

$\mathrm{Y}_{2} \mathrm{C}_{2} @ C_{3 \mathrm{~V}}(8)-\mathrm{C}_{82}$

Figure 1 Simulated structure of (a) optimized $\mathrm{Y}_{2} \mathrm{C}_{2} @ D_{5}(8)$ - $\mathrm{C}_{100}$; (b) optimized $\mathrm{Y}_{2} \mathrm{C}_{2} @ D_{3}(85)-\mathrm{C}_{92}$; (c) transition state of $\mathrm{Y}_{2} \mathrm{C}_{2} @ D_{3}(85)-\mathrm{C}_{92}$; (d) optimized $\mathrm{Y}_{2} \mathrm{C}_{2} @ C_{3 \mathrm{v}}(450)-\mathrm{C}_{100} .{ }^{\left[{ }^{[5]}\right.}$

\section{Magnetic fullerenes}

Previous researches have shown that, similar to the other molecules ${ }^{[66-68]}$, single electron in molecular orbitals would result in the paramagnetism of EMFs. ${ }^{[69,70]}$ The paramagnetic monometallofullerenes are usually based on $\mathrm{Sc}^{[71-74]} \mathrm{Y},{ }^{[75,76]}$

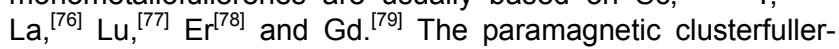
enes, on the other hand, are mostly $I_{\mathrm{h}}-\mathrm{C}_{80}$ cage based EMFs, such as $\mathrm{Sc}_{3} \mathrm{C}_{2} @ \mathrm{C}_{80},{ }^{[40]} \mathrm{ErSc}_{2} \mathrm{~N} @ \mathrm{C}_{80},{ }^{[80]} \mathrm{TiSc}_{2} \mathrm{~N} @ \mathrm{C}_{80}{ }^{[81]}$ and $\mathrm{TiY}_{2} \mathrm{~N} @ \mathrm{C}_{80}{ }^{\left[{ }^{[2]}\right.}$ In addition, some EMFs could turn to be paramagnetic with the doping of heteroatom, such as $\mathrm{Sc}_{4} \mathrm{C}_{2} \mathrm{H} @$ $\mathrm{C}_{80},{ }^{\left[{ }^{[3]}\right.} \mathrm{Y}_{2} @ \mathrm{C}_{81} \mathrm{~N}^{[84]}$ and $\mathrm{M}_{2} @ \mathrm{C}_{79} \mathrm{~N}(\mathrm{M}=\mathrm{Y}, \mathrm{Gd}) \cdot{ }^{[41,85]}$ Besides these pristine paramagnetic EMFs, diamagnetic EMFs can also be converted to paramagnetic via chemical modification. In 2010, $\mathrm{Sc}_{3} \mathrm{C}_{2} @ \mathrm{C}_{80}$ fulleropyrrolidine was synthesized by Wang and co-workers. ${ }^{[44]}$ The addend altered the spin density distributions on the molecule and induced spin divergence. As a result, the scandium hyperfine coupling constants of $\mathrm{Sc}_{3} \mathrm{C}_{2} @ \mathrm{C}_{80}$ were tuned. In a following study in 2013 , the same group used chemical reduction method to inject the electron into EMFs, and many stable paramagnetic EMFs anion radicals, i.e., $\mathrm{Sc}_{3} \mathrm{NC} @ \mathrm{C}_{80}{ }^{-{ }^{-[86]}} \mathrm{Y}_{2} @ \mathrm{C}_{82}{ }^{-{ }^{-[87]}} \mathrm{Y}_{2} \mathrm{C}_{2} @ \mathrm{C}_{82}{ }^{-{ }^{-[87]}} \mathrm{Sc}_{2} \mathrm{C}_{2} @$ $\mathrm{C}_{82}{ }^{-[87]} \mathrm{Sc}_{2} \mathrm{C}_{2} @ \mathrm{C}_{72}{ }^{-[88]}$ and $\mathrm{Y}_{3} \mathrm{~N} @ \mathrm{C}_{2 n}{ }^{-}(n=40-44),{ }^{[89]}$ were obtained. In 2015, they reported the synthesis of two novel paramagnetic EMF derivatives: $\mathrm{FSc}_{3} \mathrm{C}_{2} @ \mathrm{C}_{80} \mathrm{PNOH}$ and $\mathrm{FSc}_{3} \mathrm{C}_{2}$ $@ \mathrm{C}_{80}$ PNO $^{\circ}$ (Figure 2). ${ }^{[90]}$ In particular, they found that, with the remote nitroxide group serving as a switch in this process, the paramagnetic nitroxide radicals can switch off the ESR signals of $\mathrm{Sc}_{3} \mathrm{C}_{2} @ \mathrm{C}_{80}$ through spin-spin interaction. In this study, a series of comparative experiments were carried out by changing system temperature or elongating the distance between $\mathrm{Sc}_{3} \mathrm{C}_{2} @ \mathrm{C}_{80}$ and nitroxide radical moieties. The results show that ESR signals can also be adjusted with above-mentioned variable modifications

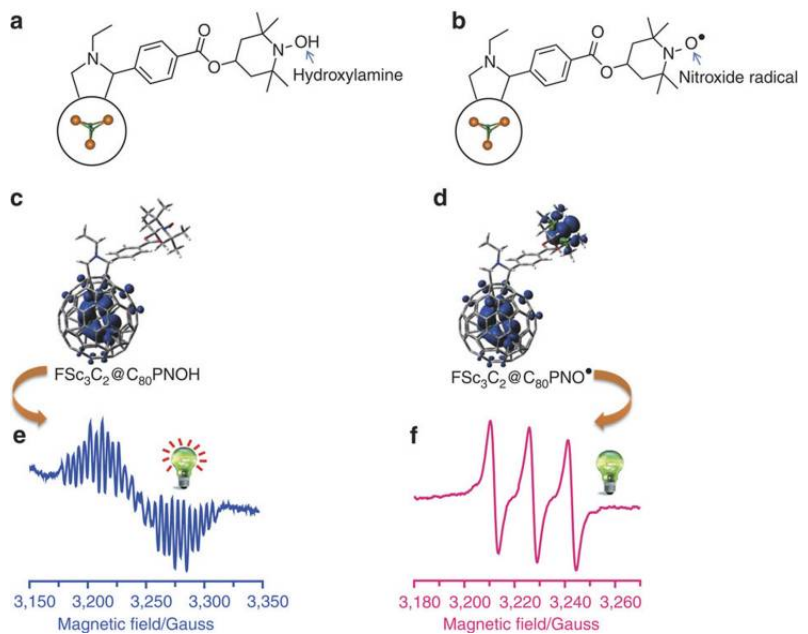

Figure 2 Magnetic switch for the ESR signals of $\mathrm{Sc}_{3} \mathrm{C}_{2} @ \mathrm{C}_{80}$. (a) The structure of $\mathrm{FSc}_{3} \mathrm{C}_{2} @ \mathrm{C}_{80} \mathrm{PNOH}$. (b) The structure of $\mathrm{FSc}_{3} \mathrm{C}_{2} @ \mathrm{C}_{80} \mathrm{PNO}$. (c) The calculated structure and spin density distributions of $\mathrm{FSc}_{3} \mathrm{C}_{2} @ \mathrm{C}_{80} \mathrm{PNOH}$. (d) The calculated structure and spin density distributions of $\mathrm{FSc}_{3} \mathrm{C}_{2} @ \mathrm{C}_{80} \mathrm{PNO}$. (e) The ESR spectrum of $\mathrm{FSc}_{3} \mathrm{C}_{2} @ \mathrm{C}_{80} \mathrm{PNOH}$ at $293 \mathrm{~K}$ in toluene. (f) The ESR spectrum of $\mathrm{FSc}_{3} \mathrm{C}_{2} @ \mathrm{C}_{80} \mathrm{PNO}$ at $293 \mathrm{~K}$ in toluene. The lamps in e and f show the 'on' and 'off' states of $\mathrm{Sc}_{3} \mathrm{C}_{2} @ \mathrm{C}_{80}$ ESR signals, respectively. ${ }^{[90]}$

The $4 \mathrm{f}$ levels of lanthanide ions have an unquenched orbital moment, and the orbital coupling gives rise to single-molecule magnetism of EMFs. ${ }^{[91]}$ EMFs based single molecule magnets have been a rapid developing research area in the recent years. ${ }^{[46,47,92]}$ In 2012, Greber and Dunsch ${ }^{[91]}$ found that $\mathrm{DySc}_{2} \mathrm{~N}$ $@ \mathrm{C}_{80}$ exhibited a hysteresis of magnetization with zero-field quantum tunneling of magnetization, which was the first reported EMF based single molecule magnet. Later, they found that the ferromagnetic coupling of individual dysprosium moments in $\mathrm{Dy}_{2} \mathrm{ScN} @ \mathrm{C}_{80}$ is even higher than that in $\mathrm{DySc}_{2} \mathrm{~N} @ \mathrm{C}_{80}$. Thus, SMM properties of $\mathrm{Dy}_{2} \mathrm{ScN} @ \mathrm{C}_{80}$ are better than $\mathrm{DySc}_{2} \mathrm{~N} @ \mathrm{C}_{80}$. The blocking temperature of $\mathrm{Dy}_{2} \mathrm{ScN} @ \mathrm{C}_{80}$ is $7 \mathrm{~K}$ higher than $6 \mathrm{~K}$ of $\mathrm{DySc}_{2} \mathrm{~N} @ \mathrm{C}_{80}$. However, no SMM property was found for $\mathrm{Dy}_{3} \mathrm{~N} @ \mathrm{C}_{80}$ due to the fully frustrated ferromagnetic coupling in it. ${ }^{[93]}$ Popov and Yang studied the SMM 


\section{General Chemistry}

properties of a series of EMFs including $\mathrm{Dy}_{2} \mathrm{TiC}_{2} @ \mathrm{C}_{80},{ }^{[94]}$ $\mathrm{Dy}_{2} \mathrm{TiC} @ \mathrm{C}_{80},{ }^{[94]} \mathrm{TbNC}_{0} \mathrm{C}_{76},{ }^{[92]} \mathrm{TbNC} @ \mathrm{C}_{82},{ }^{[95]} \mathrm{Dy}_{2} \mathrm{~S} @ \mathrm{C}_{82}{ }^{[47]}$ and $\mathrm{Dy}_{2} \mathrm{ScN} @ \mathrm{C}_{80}{ }^{[93,96]}$ They found that $\mathrm{Dy}_{2} \mathrm{ScN} @ \mathrm{C}_{80}$ is the best single-molecule magnet among all the above- mentioned EMFs. The superior magnetic property of this molecule could be assigned to its short Dy- $\mathrm{N}$ distance and strong dipolar coupling. On the contrary, $\mathrm{Dy}_{2} \mathrm{~S} @ \mathrm{C}_{82}, \mathrm{Dy}_{2} \mathrm{TiC}_{2} @ \mathrm{C}_{80}$ and TbNC@ $\mathrm{C}_{82}$ exhibited notable lower blocking tempera- ture, mainly due to their longer Dy-M (M = S, $\left.C_{2}, N C\right)$ distances and smaller magnetic anisotropy axes angle. ${ }^{[47]}$ Very recently, Popov and colleagues synthesized two novel EMFs based single molecule magnets: $\mathrm{M}_{2} @ \mathrm{C}_{80}\left(\mathrm{CH}_{2} \mathrm{Ph}\right)(\mathrm{M}=\mathrm{Dy}, \mathrm{Y})$ (Figure 3). ${ }^{[97]}$ In particular, $\mathrm{Dy}_{2} @ \mathrm{C}_{80}\left(\mathrm{CH}_{2} \mathrm{Ph}\right)$ exhibited unprecedentedly high blocking temperature, which is the highest among all the single molecule magnet discovered so far. The large net magnetic moment and high blocking temperature were ascribed to the strong ferromagnetic coupling via unpaired electron between the two Dy ions, which is trapped by the $\left[D y^{3+}-e-D y^{3+}\right]$ unit.

a
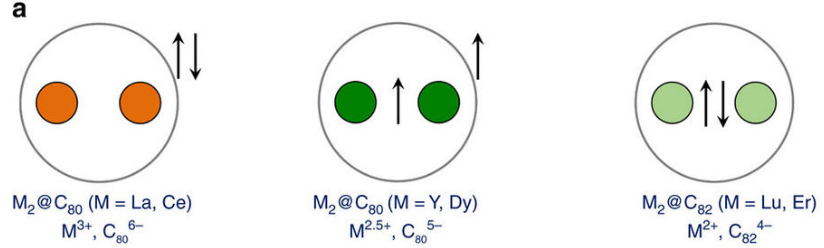

b

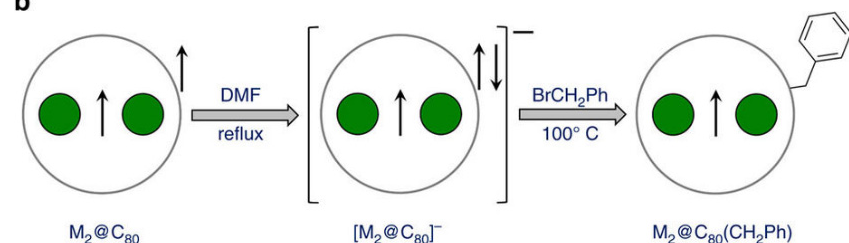

Figure 3 Schematic depiction of dimetallofullerenes and synthetic route to $\mathrm{M}_{2} @ \mathrm{C}_{80}\left(\mathrm{CH}_{2} \mathrm{Ph}\right)$ derivatives. (a) Comparison between different types of dimetallofullerenes: in $\mathrm{La}_{2} @ \mathrm{C}_{80}$ each metal atom is trivalent, transfers three electrons to the cage and the $\mathrm{M}-\mathrm{M}$ bonding $\mathrm{MO}$ is the LUMO; in $\mathrm{M}_{2} @ \mathrm{C}_{80}(\mathrm{M}=\mathrm{Y}, \mathrm{Dy})$ studied in this work, each metal formally transfers 2.5 electrons to the cage and the $\mathrm{M}-\mathrm{M}$ bonding $\mathrm{MO}$ is single occupied; in $\mathrm{M}_{2} @ \mathrm{C}_{82}(\mathrm{M}=\mathrm{Er}, \mathrm{Lu})$, metals transfer two electrons each and form two-electron M-M covalent bond. (b) Description of the synthetic route for $\mathrm{M}_{2} @ \mathrm{C}_{80}$ derivative with single-electron $\mathrm{M}-\mathrm{M}$ bond developed in this work $\left(\mathrm{M}^{1} / 4 \mathrm{Y}, \mathrm{Dy}\right): \mathrm{M}_{2} @ \mathrm{C}_{80}$ molecules synthesized by arc-discharge are present in triplet state in the soot; upon reduction with DMF, soluble mono-anions are formed, the surplus electron goes to the cage and the $M-M$ SOMO is preserved. At the next stage, anions are reacted with benzyl bromide, which leads to stable non-charged mono-adducts. These adducts are further separated by HPLC. ${ }^{[97]}$

\section{Summary and Outlook}

This minireview highlights the recent research development in the EMFs, focusing on the large EMFs and magnetic fullerenes reported to date. This research shows that the versatility of the carbon cages and the entrapped groups endow EMFs with fascinating structures and peculiar properties. For large EMFs, the cage size is relatively big for the entrapped cluster and the cage-cluster interaction becomes significant. On the other hand, recent research revealed that magnetic properties of EMFs could be controlled and modified by both endohedral clusters and exohedral chemical modifications. Exohedral chemical modification can also switch on and off the para- magnetic properties of the EMFs. The variable structures of encapsulated clusters lead to diverse magnetic properties of the single molecule magnet. This research reveals the connection between the versatile molecular structure of EMFs and resulting intriguing properties and sheds light on the practical applications of them in the field of molecular devices in the near future.

\section{Acknowledgement}

This work is supported in part by the National Science Foundation of China (No. 51772196), the Natural Science Foundation of Jiangsu Province (No. BK20171211), the Priority Academic Program Development of Jiangsu Higher Education Institutions (PAPD) and the Project of Scientific and Technologic Infrastructure of Suzhou (No. SZS201708).

\section{References}

[1] Kroto, H. W.; Heath, J. R.; O'Brien, S. C.; Curl, R. F.; Smalley, R. E. Nature 1985, 318, 162.

[2] Shen, W.; Bao, L.; Wu, Y.; Pan, C.; Zhao, S.; Fang, H.; Xie, Y.; Jin, P.; Peng, P.; Li, F.-F.; Lu, X. J. Am. Chem. Soc. 2017, 139, 9979.

[3] Bao, L.; Chen, M.; Pan, C.; Yamaguchi, T.; Kato, T.; Olmstead, M. M.; Balch, A. L.; Akasaka, T.; Lu, X. Angew. Chem. 2016, 128, 4314.

[4] Sado, Y.; Aoyagi, S.; Izumi, N.; Kitaura, R.; Kowalczyk, T.; Wang, J.; Irle, S.; Nishibori, E.; Sugimoto, K.; Shinohara, H. Chem. Phys. Lett. 2014, 600, 38.

[5] Wang, Y.; Tang, Q.; Feng, L.; Chen, N. Inorg. Chem. 2017, 56, 1974.

[6] Tang, Q.; Abella, L.; Hao, Y.; Li, X.; Wan, Y.; Rodriguez-Fortea, A.; Poblet, J. M.; Feng, L.; Chen, N. Inorg. Chem. 2016, 55, 1926.

[7] Cai, W.; Li, F.-F.; Bao, L.; Xie, Y.; Lu, X. J. Am. Chem. Soc. 2016 , 138,6670 .

[8] Abella, L.; Tang, Q.; Zhang, X.; Wang, Y.; Chen, N.; Poblet, J. M.; Rodríguez-Fortea, A. J. Phys. Chem. C 2016, 120, 26159.

[9] Akasaka, T.; Okubo, S.; Kondo, M.; Maeda, Y.; Wakahara, T.; Kato, T.; Suzuki, T.; Yamamoto, K.; Kobayashi, K.; Nagase, S. Chem. Phys. Lett. 2000, 319, 153.

[10] Maeda, Y.; Miyashita, J.; Hasegawa, T.; Wakahara, T.; Tsuchiya, T.; Feng, L.; Lian, Y.; Akasaka, T.; Kobayashi, K.; Nagase, S. J. Am. Chem. Soc. 2005, 127, 2143.

[11] Popov, A. A.; Yang, S.; Dunsch, L. Chem. Rev. 2013, 113, 5989

[12] Reich, A.; Panthöfer, M.; Modrow, H.; Wedig, U.; Jansen, M. J. Am. Chem. Soc. 2004, 126, 14428.

[13] Cai, W.; Morales-Martinez, R.; Zhang, X.; Najera, D.; Romero, E. L.; Metta-Magana, A.; Rodriguez-Fortea, A.; Fortier, S.; Chen, N.; Poblet, J. M.; Echegoyen, L. Chem. Sci. 2017, 8, 5282.

[14] Yang, S.; Dunsch, L. Angew. Chem., Int. Ed. 2006, 45, 1299.

[15] Beavers, C. M.; Jin, H.; Yang, H.; Wang, Z.; Wang, X.; Ge, H.; Liu, Z.; Mercado, B. Q.; Olmstead, M. M.; Balch, A. L. J. Am. Chem. Soc. 2011, 133, 15338.

[16] Fu, W.; Zhang, J.; Fuhrer, T.; Champion, H.; Furukawa, K.; Kato, T.; Mahaney, J. E.; Burke, B. G.; Williams, K. A.; Walker, K.; Dixon, C.; Ge, J.; Shu, C.; Harich, K.; Dorn, H. C. J. Am. Chem. Soc. 2011, 133, 9741.

[17] Popov, A. A.; Zhang, L.; Dunsch, L. ACS Nano 2010, 4, 795.

[18] Krause, M.; Dunsch, L. Chem. Phys. Chem. 2004, 5, 1445.

[19] Chen, N.; Zhang, E.-Y.; Wang, C.-R. J. Phys. Chem. B 2006, 110, 13322.

[20] Chen, N.; Fan, L.-Z.; Tan, K.; Wu, Y.-Q.; Shu, C.-Y.; Lu, X.; Wang, C.-R. J. Phys. Chem. C 2007, 111, 11823.

[21] Zhang, L.; Popov, A. A.; Yang, S.; Klod, S.; Rapta, P.; Dunsch, L. Phys. Chem. Chem. Phys. 2010, 12, 7840.

[22] Wang, C.-R.; Kai, T.; Tomiyama, T.; Yoshida, T.; Kobayashi, Y.; 
Nishibori, E.; Takata, M.; Sakata, M.; Shinohara, H. Angew. Chem., Int. Ed. 2001, 40, 397

[23] Lu, X.; Nakajima, K.; liduka, Y.; Nikawa, H.; Tsuchiya, T.; Mizorogi, N.; Slanina, Z.; Nagase, S.; Akasaka, T. Angew. Chem., Int. Ed. 2012, 51, 5889.

[24] Kurihara, H.; Lu, X.; liduka, Y.; Mizorogi, N.; Slanina, Z.; Tsuchiya, T.; Akasaka, T.; Nagase, S. J. Am. Chem. Soc. 2011, 133, 2382.

[25] Chen, C.-H.; Ghiassi, K. B.; Cerón, M. R.; Guerrero-Ayala, M. A.; Echegoyen, L.; Olmstead, M. M.; Balch, A. L. J. Am. Chem. Soc. 2015, 137, 10116

[26] Krause, M.; Ziegs, F.; Popov, A. A.; Dunsch, L. Chem. Phys. Chem. 2007, 8, 537.

[27] Liu, F.; Wang, S.; Guan, J.; Wei, T.; Zeng, M.; Yang, S. Inorg. Chem. 2014, 53, 5201.

[28] Wang, T.-S.; Feng, L.; Wu, J.-Y.; Xu, W.; Xiang, J.-F.; Tan, K.; Ma, Y.-H.; Zheng, J.-P.; Jiang, L.; Lu, X.; Shu, C.-Y.; Wang, C.-R. J. Am. Chem. Soc. 2010, 132, 16362.

[29] Chen, N.; Mulet-Gas, M.; Li, Y.-Y.; Stene, R. E.; Atherton, C. W.; Rodriguez-Fortea, A.; Poblet, J. M.; Echegoyen, L. Chem. Sci. 2013, 4, 180.

[30] Chen, N.; Beavers, C. M.; Mulet-Gas, M.; Rodríguez-Fortea, A.; Munoz, E. J.; Li, Y.-Y.; Olmstead, M. M.; Balch, A. L.; Poblet, J. M.; Echegoyen, L. J. Am. Chem. Soc. 2012, 134, 7851.

[31] Yang, T.; Hao, Y.; Abella, L.; Tang, Q.; Li, X.; Wan, Y.; Rodríguez-Fortea, A.; Poblet, J. M.; Feng, L.; Chen, N. Chem. Eur. J. 2015, 21, 11110 .

[32] Stevenson, S.; Mackey, M. A.; Stuart, M. A.; Phillips, J. P.; Easterling, M. L.; Chancellor, C. J.; Olmstead, M. M.; Balch, A. L. J. Am. Chem. Soc. 2008, 130, 11844.

[33] Cai, W.; Bao, L.; Zhao, S.; Xie, Y.; Akasaka, T.; Lu, X. J. Am. Chem. Soc. 2015, 137, 10292.

[34] Curl, R. F. Angew. Chem., Int. Ed. 1997, 36, 1566.

[35] Chen, C.-H.; Abella, L.; Cerón, M. R.; Guerrero-Ayala, M. A.; Rodríguez-Fortea, A.; Olmstead, M. M.; Powers, X. B.; Balch, A. L.; Poblet, J. M.; Echegoyen, L. J. Am. Chem. Soc. 2016, 138, 13030.

[36] Yang, S.; Wei, T.; Jin, F. Chem. Soc. Rev. 2017, 46, 5005.

[37] Wolf, M.; Müller, K. H.; Skourski, Y.; Eckert, D.; Georgi, P.; Krause, M.; Dunsch, L. Angew. Chem., Int. Ed. 2005, 44, 3306.

[38] Smirnova, T. I.; Smirnov, A. I.; Chadwick, T. G.; Walker, K. L. Chem. Phys. Lett. 2008, 453, 233

[39] Chen, L.; Carpenter, E. E.; Hellberg, C. S.; Dorn, H. C.; Shultz, M.; Wernsdorfer, W.; Chiorescu, I. J. Appl. Phys. 2011, 109, $07 \mathrm{~B} 101$.

[40] Van Loosdrecht, P.; Johnson, R.; De Vries, M.; Kiang, C.-H.; Bethune, D.; Dorn, H.; Burbank, P.; Stevenson, S. Phys. Rev. Lett. 1994, 73, 3415.

[41] Zuo, T.; Xu, L.; Beavers, C. M.; Olmstead, M. M.; Fu, W.; Crawford, T. D.; Balch, A. L.; Dorn, H. C. J. Am. Chem. Soc. 2008, 130, 12992.

[42] Popov, A. A.; Chen, N.; Pinzón, J. R.; Stevenson, S.; Echegoyen, L. A.; Dunsch, L. J. Am. Chem. Soc. 2012, 134, 19607.

[43] Popov, A. A.; Dunsch, L. J. Am. Chem. Soc. 2008, 130, 17726.

[44] Wang, T.; Wu, J.; Xu, W.; Xiang, J.; Lu, X.; Li, B.; Jiang, L.; Shu, C.; Wang, C. Angew. Chem., Int. Ed. 2010, 49, 1786.

[45] Westerström, R.; Dreiser, J.; Piamonteze, C.; Muntwiler, M.; Weyeneth, S.; Brune, H.; Rusponi, S.; Nolting, F.; Popov, A.; Yang, S. J. Am. Chem. Soc. 2012, 134, 9840.

[46] Krylov, D. S.; Liu, F.; Avdoshenko, S. M.; Spree, L.; Weise, B.; Waske, A.; Wolter, A. U. B.; Buchner, B.; Popov, A. A. Chem. Commun. 2017, 53, 7901

[47] Chen, C.-H.; Krylov, D. S.; Avdoshenko, S. M.; Liu, F.; Spree, L.; Yadav, R.; Alvertis, A.; Hozoi, L.; Nenkov, K.; Kostanyan, A. Chem. Sci. 2017, 8, 6451.

[48] Liu, F.; Gao, C.-L.; Deng, Q.; Zhu, X.; Kostanyan, A.; Westerström, R.; Wang, S.; Tan, Y.-Z.; Tao, J.; Xie, S.-Y.; Popov, A. A.; Greber, T.; Yang, S. J. Am. Chem. Soc. 2016, 138, 14764

[49] Leuenberger, M. N.; Loss, D. Nature 2001, 410, 789.
[50] Bogani, L.; Wernsdorfer, W. Nat. Mater. 2008, 7, 179.

[51] Wang, S.; Yang, S.; Kemnitz, E.; Troyanov, S. I. Angew. Chem., Int. Ed. 2016, 55, 3451.

[52] Yang, H.; Jin, H.; Hong, B.; Liu, Z.; Beavers, C. M.; Zhen, H.; Wang, Z.; Mercado, B. Q.; Olmstead, M. M.; Balch, A. L. J. Am. Chem. Soc. 2011, 133, 16911.

[53] Yang, H.; Beavers, C. M.; Wang, Z.; Jiang, A.; Liu, Z.; Jin, H.; Mercado, B. Q.; Olmstead, M. M.; Balch, A. L. Angew. Chem., Int. Ed. 2010, 49, 886.

[54] Wang, S.; Yang, S.; Kemnitz, E.; Troyanov, S. I. Inorg. Chem. 2016, 55, 5741 .

[55] Che, Y.; Yang, H.; Wang, Z.; Jin, H.; Liu, Z.; Lu, C.; Zuo, T.; Dorn, H. C.; Beavers, C. M.; Olmstead, M. M.; Balch, A. L. Inorg. Chem. 2009, 48, 6004.

[56] Yang, H.; Jin, H.; Zhen, H.; Wang, Z.; Liu, Z.; Beavers, C. M.; Mercado, B. Q.; Olmstead, M. M.; Balch, A. L. J. Am. Chem. Soc. 2011, 133, 6299

[57] Jin, H.; Yang, H.; Yu, M.; Liu, Z.; Beavers, C. M.; Olmstead, M. M.; Balch, A. L. J. Am. Chem. Soc. 2012, 134, 10933.

[58] Zhao, P.; Guo, Y.-J.; Zhao, R.-S.; Zhao, X. Chem. Phys. Lett. 2016, 644,35 .

[59] Mercado, B. Q.; Jiang, A.; Yang, H.; Wang, Z.; Jin, H.; Liu, Z.; Olmstead, M. M.; Balch, A. L. Angew. Chem., Int. Ed. 2009, 48, 9114.

[60] Zhao, S.; Zhao, P.; Cai, W.; Bao, L.; Chen, M.; Xie, Y.; Zhao, X.; Lu, X. J. Am. Chem. Soc. 2017, 139, 4724

[61] Yang, H.; Lu, C.; Liu, Z.; Jin, H.; Che, Y.; Olmstead, M. M.; Balch, A. L. J. Am. Chem. Soc. 2008, 130, 17296.

[62] Chaur, M. N.; Valencia, R.; Rodríguez-Fortea, A.; Poblet, J. M.; Echegoyen, L. Angew. Chem., Int. Ed. 2009, 48, 1425.

[63] Yang, S.; Dunsch, L. J. Phys. Chem. B 2005, 109, 12320.

[64] Chaur, M. N.; Melin, F.; Elliott, B.; Kumbhar, A.; Athans, A. J.; Echegoyen, L. Chem. Eur. J. 2008, 14, 4594.

[65] Zhang, J.; Fuhrer, T.; Fu, W.; Ge, J.; Bearden, D. W.; Dallas, J.; Duchamp, J.; Walker, K.; Champion, H.; Azurmendi, H.; Harich, K.; Dorn, H. C. J. Am. Chem. Soc. 2012, 134, 8487.

[66] Back, P.; Sidler, M.; Cotlet, O.; Srivastava, A.; Takemura, N.; Kroner, M.; Imamoğlu, A. Phys. Rev. Lett. 2017, 118, 237404.

[67] Wang, F.; Kivelson, S. A.; Lee, D.-H. Nat. Phys. 2015, 11, 959

[68] Iqbal, Y.; Jeschke, H. O.; Reuther, J.; Valentí, R.; Mazin, I.; Greiter, M.; Thomale, R. Phys. Rev. B 2015, 92, 220404.

[69] Farrington, B.; Jevric, M.; Rance, G.; Ardavan, A.; Khlobystov, A. Briggs, G.; Porfyrakis, K. Angew. Chem., Int. Ed. 2012, 51, 3587.

[70] Lu, X.; Akasaka, T.; Nagase, S. Chem. Commun. 2011, 47, 5942.

[71] Yannoni, C. S.; Hoinkis, M.; de Vries, M. S.; Bethune, D. S.; Salem, J. R.; Crowder, M. S.; Johnson, R. D. Science 1992, 256, 1191.

[72] Morley, G.; Herbert, B.; Lee, S.; Porfyrakis, K.; Dennis, T.; NguyenManh, D.; Scipioni, R.; Van Tol, J.; Horsfield, A.; Ardavan, A Nanotechnology 2005, 16, 2469.

[73] Suzuki, S.; Kawata, S.; Shiromaru, H.; Yamauchi, K.; Kikuchi, K.; Kato, T.; Achiba, Y. J. Phys. Chem. 1992, 96, 7159.

[74] Inakuma, M.; Shinohara, H. J. Phys. Chem. B 2000, 104, 7595.

[75] Misochko, E. Y.; Akimov, A. V.; Belov, V. A.; Tyurin, D. A.; Bubnov, V. P.; Kareev, I. E.; Yagubskii, E. B. Phys. Chem. Chem. Phys 2010, 12, 8863.

[76] Okubo, S.; Kato, T. Appl. Magn. Reson. 2003, 23, 481.

[77] Knapp, C.; Weiden, N.; Dinse, K.-P. Appl. Phys. A 1998, 66, 249.

[78] Sanakis, Y.; Tagmatarchis, N.; Aslanis, E.; loannidis, N.; Petrouleas, V.; Shinohara, H.; Prassides, K. J. Am. Chem. Soc. 2001, 123, 9924.

[79] Furukawa, K.; Okubo, S.; Kato, H.; Shinohara, H.; Kato, T. J. Phys. Chem. A 2003, 107, 10933.

[80] Morton, J. J.; Tiwari, A.; Dantelle, G.; Porfyrakis, K.; Ardavan, A.; Briggs, G. A. D. Phys. Rev. Lett. 2008, 101, 013002

[81] Popov, A. A.; Chen, C.; Yang, S.; Lipps, F.; Dunsch, L. ACS Nano 2010, 4,4857 


\section{General Chemistry}

[82] Chen, C.; Liu, F.; Li, S.; Wang, N.; Popov, A. A.; Jiao, M.; Wei, T.; Li, Q.; Dunsch, L.; Yang, S. Inorg. Chem. 2012, 51, 3039.

[83] Feng, Y.; Wang, T.; Wu, J.; Zhang, Z.; Jiang, L.; Han, H.; Wang, C. Chem. Commun. 2014, 50, 12166.

[84] Zhang, Z.; Wang, T.; Xu, B.; Wang, C. Dalton Trans. 2014, 43, 12871.

[85] Fu, W.; Zhang, J.; Fuhrer, T.; Champion, H.; Furukawa, K.; Kato, T.; Mahaney, J. E.; Burke, B. G.; Williams, K. A.; Walker, K. J. Am. Chem. Soc. 2011, 133, 9741.

[86] Feng, Y.; Wang, T.; Wu, J.; Ma, Y.; Zhang, Z.; Jiang, L.; Ge, C.; Shu, C.; Wang, C. Chem. Commun. 2013, 49, 2148.

[87] Ma, Y.; Wang, T.; Wu, J.; Feng, Y.; Li, H.; Jiang, L.; Shu, C.; Wang, C. J. Phys. Chem. Lett. 2013, 4, 464.

[88] Feng, Y.; Wang, T.; Wu, J.; Feng, L.; Xiang, J.; Ma, Y.; Zhang, Z.; Jiang, L.; Shu, C.; Wang, C. Nanoscale 2013, 5, 6704.

[89] Zhao, C.; Wang, T.; Li, Y.; Meng, H.; Nie, M.; Tian, J.; Wang, C. Phys. Chem. Chem. Phys. 2017, 19, 26846.

[90] Wu, B.; Wang, T.; Feng, Y.; Zhang, Z.; Jiang, L.; Wang, C. Nat. Commun. 2015, 6, 6468.

[91] Westerström, R.; Dreiser, J.; Piamonteze, C.; Muntwiler, M.; Weyeneth, S.; Brune, H.; Rusponi, S.; Nolting, F.; Popov, A.; Yang, S.; Dunsch, L.; Greber, T. J. Am. Chem. Soc. 2012, 134, 9840.

[92] Liu, F.; Wang, S.; Gao, C. L.; Deng, Q.; Zhu, X.; Kostanyan, A.;
Westerström, R.; Jin, F.; Xie, S. Y.; Popov, A. A. Angew. Chem., Int. Ed. 2017, 129, 1856.

[93] Westerström, R.; Dreiser, J.; Piamonteze, C.; Muntwiler, M.; Weyeneth, S.; Krämer, K.; Liu, S.-X.; Decurtins, S.; Popov, A.; Yang, S. Phys. Rev. B 2014, 89, 060406.

[94] Junghans, K.; Schlesier, C.; Kostanyan, A.; Samoylova, N. A.; Deng, Q.; Rosenkranz, M.; Schiemenz, S.; Westerström, R.; Greber, T.; Büchner, B. Angew. Chem., Int. Ed. 2015, 54, 13411.

[95] Liu, F.; Gao, C.-L.; Deng, Q.; Zhu, X.; Kostanyan, A.; Westerström, R.; Wang, S.; Tan, Y.-Z.; Tao, J.; Xie, S.-Y. J. Am. Chem. Soc. 2016, 138, 14764

[96] Krylov, D.; Liu, F.; Avdoshenko, S.; Spree, L.; Weise, B.; Waske, A.; Wolter, A.; Buechner, B.; Popov, A. A. Chem. Commun. 2017 $53,7901$.

[97] Liu, F.; Krylov, D. S.; Spree, L.; Avdoshenko, S. M.; Samoylova, N. A.; Rosenkranz, M.; Kostanyan, A.; Greber, T.; Wolter, A. U.; Büchner, B. Nat. Commun. 2017, 8. 16098.

Received January 19, 2018

Accepted February 27, 2018 